\title{
BIOACTIVITY OF TEPA (Laureliopsis philippiana (LOOSER) SHODDE) POWDER TO Sitophilus zeamais Motschulsky CONTROL IN LABORATORY
}

\author{
Ana Ortiz U. ${ }^{1}$, Gonzalo Silva A. . ${ }^{*}$, Angélica Urbina P. ${ }^{1}$, Nelson Zapata S.M. ${ }^{1}$, \\ J. Concepción Rodríguez M. ${ }^{2}$, and Angel Lagunes T. ${ }^{2}$
}

The maize weevil (Sitophilus zeamais Motschulsky) is one of the most widespread pests and causes heavy losses of stored grain throughout the world. Control of this insect is primarily dependent upon continued applications of organophosphorus and pyrethroid insecticides and fumigants as phosphine but the increasing problems with current insecticides drive the need for research and to develop new control methods. The insecticidal effect of leaf powder of tepa, Laureliopsis philippiana (Looser) Shodde, was evaluated against maize weevil under laboratory conditions. The parameters evaluated were adult mortality and emergence, grain weight loss and germination, and residual, repellent and fumigant effect. The highest levels of insect mortality were registered with treatments at 1,2 , and $4 \%$, with values from 94.7 to $100 \%$. Also, it was obtained $0 \%$ of adult insect emergence with these concentrations. In all treatments grain weight was less than $5.8 \mathrm{~g}$. Seed germination was not affected. The powder of L. philippiana exhibited repellent effect in all concentrations and did not show fumigant effect. Insecticidal effect of powder remained for $14 \mathrm{~d}$. Finally, we concluded that powder of L. philippiana has great potential for controlling S. zeamais.

Key words: Stored grains, botanical insecticides, maize weevil.

A ccording to Larraín (1994) about $10 \%$ of the grains are contaminated by insects, or their eggs, and if the infestation continues in storage, about 30 to $50 \%$ of the grains may be damaged after 6-mo. The situation is especially relevant in developing countries where the small farmers have their stored grain attacked by rodents, insects, fungi, and mites (Celis and Kunadu-Yiadom, 1992).

The most important insect pests of stored grain in Chile are the maize weevil (Sitophilus zeamais Motschulsky, Coleoptera: Curculionidae), the rice weevil (Sitophilus oryzae Linnaeus, Coleoptera: Curculionidae), and the grain moth (Ephestia kuehniella Zeller, Lepidoptera: Pyralidae) (Larraín, 1994). Of these species $S$.zeamais is particularly important, because is a cosmopolitan pest, capable of damaging grains before and after the harvest, and for this reason is considered a key pest (González, 1989).

The spray of synthetic insecticides is the most widely practice to minimize insect pest populations. However, not informed use of such substances can lead to resistance problems, environmental pollution, residues in food, and accidents (Rodríguez and Lagunes, 1992; Coats,

${ }^{1}$ Universidad de Concepción, Facultad de Agronomía, Av. Vicente Méndez 595, Casilla 537, Chillán, Chile.

*Corresponding author (gosilva@udec.cl).

${ }^{2}$ Colegio de Postgraduados, Programa de Entomología y Acarología, km 36.5 Carretera México-Texcoco, CP 56230, Montecillo, Estado de México, México.

Received: 30 March 2011.

Accepted: 20 December 2011
1994; Novo et al., 1997; Rafael et al., 1999). Some nonchemical practices used by farmers to reduce the pest incidence during storage are the use of sand, clay, ash, and oil mixed with the grains. These materials, besides being a physical barrier between the insect and the seed, affect the insect cuticular wax which provokes dehydration and death (Celis and Kunadu-Yiadom, 1992). However, these practices became less relevant with the advent of synthetic insecticides (Isman, 2006).

In Chile we have studied several control options against maize weevil using natural compounds, such as medicinal plants (Silva et al., 2003b; Pérez et al., 2007; Bustos et al., 2009; Cruzat et al., 2009), aromatic plants (Salvadores et al., 2007), and inert minerals (Silva et al., 2004). Promissory results were obtained with Peumus boldus Molina (Monimiaceae) in concentrations of 1 and 2\% showing 100\% mortality (Silva et al., 2003a; Pérez et al., 2007; Cruzat et al., 2009). Another alternative for small maize farmers especially in southern Chile could be the use of tepa or huanhuan (Laureliopsis philippiana (Looser) Schodde) (McLemore et al., 1999). Previous studies have determined fungicidal and insecticidal activity of essential oils of leaves of L. philippiana (Bittner et al., 2008; 2009) but have only been evaluated mortality until $72 \mathrm{~h}$ and several botanical insecticides have many other properties as repellence, fumigant and feed and oviposition deterrence.

The objective of this research was assessing the insecticidal properties of L. philippiana leaf powder to control S. zeamais under laboratory conditions. 


\section{MATERIALS AND METHODS}

\section{Vegetal material and maize grain}

Laureliopsis philippiana foliage was collected from the

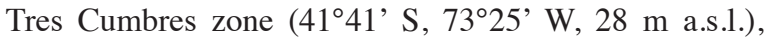
province of Maullín, Los Lagos Region, Chile, using the Vogel et al. (1997) criteria. Once collected, leaves were dried during $48 \mathrm{~h}$ in a stove (Memmert Gmbh, UNB 500, Schwabach, Germany) at $40{ }^{\circ} \mathrm{C}$. After that, the foliage was ground in an electric coffee grinder (Moulinex ultra 505) to obtain a fine powder with a 20 mesh $(0.841 \mathrm{~mm})$ sieve (Dual Manufacturing Co., Chicago, Illinois, USA).

Maize grains (Zea mays L.) with 14\% moisture were used as alimentary substrate. The maize was obtained in the market in Chillan, Chile. To avoid any prior infestation the grain was washed and frozen at $-4 \pm 1^{\circ} \mathrm{C}$ for $48 \mathrm{~h}$.

\section{Insects and insecticidal properties}

The insects used in the bioassays were obtained from the Laboratory of Entomology, Facultad de Agronomía, Universidad de Concepción. They were reproduced in 1 $\mathrm{L}$ glass flasks containing maize as a source of food. The insects were maintained in total darkness at a temperature of $30 \pm 1^{\circ} \mathrm{C}$ in a bioclimatic chamber (Memmert Gmbh, IPS 749, Schwabach, Germany).

The experimental bioassay for insecticidal properties was based on Tavares and Vendramin (2005). Plastic Petri dishes ( $5 \mathrm{~cm}$ diameter) filled with $20 \mathrm{~g}$ of maize mixed with L. philippiana powder at concentrations of $0.25,0.5$, 1,2 and $4 \%(\mathrm{w} / \mathrm{w})$ were then infested with 10 couples of insects no more than $10 \mathrm{~d}$ old. Sex differentiation was made according to Halstead (1963) criteria. The control consisted only in the maize infested with the insects. Each treatment had five replicates and was repeated three times on different days.

At $15 \mathrm{~d}$ after infestation (DAI), all insect were retired and the percentage of mortality was recording and corrected with the Abbott (1925) formula. Then, at 55 DAI, the percentage of adult emergence $\left(\mathrm{F}_{1}\right)$, considering as $100 \%$ the control emergence, and grain weight loss, based on the difference between the initial $(20 \mathrm{~g})$ and final weights were determined. Finally, at 55 DAI treatment's toxicity on the germination of maize mixed with $L$. phillipiana powder was evaluated selecting 10 seeds apparently healthy, which were germinated for $1 \mathrm{wk}$ at room temperature $\left(22 \pm 2{ }^{\circ} \mathrm{C}\right)$ in Petri dishes equipped with wet filter paper. The control germination was considered as $100 \%$.

\section{Repellent effect}

The methodology proposed by Mazzonetto and Vendramim (2003), with slight modifications, was used to assess the repellent effect of the powder of $L$. phillipiana. The experimental unit was a plastic Petri dish (5 $\mathrm{cm}$ diameter) containing $50 \mathrm{~g}$ of maize grains mixed with the different concentrations of powder: 0 (control);
$0.125,0.25,0.5,1,2$, and $4 \%$. Treatments were evaluated separately and were placed intercalated with control in a circle around a central Petri dish contained 20 individuals of $S$. zeamais of $48 \mathrm{~h}$ of age, without sexing. The central Petri dish was connected to the others through tubes 10 $\mathrm{cm}$ long and $0.5 \mathrm{~cm}$ in diameter (Procopio et al., 2003). The experimental batch was maintained in a bioclimatic chamber for $24 \mathrm{~h}$ at $30 \pm 1{ }^{\circ} \mathrm{C}$. Subsequently, the number of insects present in each treatment was counted. Each treatment had 10 replicates and in each replicate the treatments locations were randomly rotated to avoid external factors interference. The repellent index was calculated with these results according to Mazzonetto and Vendramim (2003), who classified the powder as neutral if the index $=1$, attracting if $>1$ and repellent if $<1$.

\section{Fumigant effect}

The methodology was adapted from Tavares and Vendramin (2005). In the bottom of $200 \mathrm{~mL}$ plastic containers was inserted a PVC tube of $5 \mathrm{~cm}$ long and $2.5 \mathrm{~cm}$ in diameter, containing L. philippiana powder at concentrations of $0.25,0.5,1,2$, and $4 \%$. Then, PVC tubes were covered with a piece of fine organza fabric to prevent direct contact of insects with the powder but allowing release of volatile compounds into the environment. Outside of the tube and the inner edge of the plastic containers was filled with 20 $\mathrm{g}$ of maize, which were infested with 20 unsexed insects. The mortality assessment by the fumigant effect was made 5 DAI. Each treatment consisted of five replicates and the complete group of treatments was repeated three times on different days.

\section{Residual effect}

In the essay of residual effect, we evaluated the concentrations of 1,2 , and $4 \%$ of L. philippiana leaves powder because showed a contact mortality of $S$. zeamais superior to $80 \%$ and according to Salvadores et al. (2007) is considered as promising. In a plastic Petri dish $(5 \mathrm{~cm}$ in diameter) $20 \mathrm{~g}$ of maize were placed and infested with 20 insect without sex differentiation. Later maize was mixed manually with recently processed vegetable powder. At the same time, the remaining powder was stored in two opaque hermetic and closed containers, of which one was kept under refrigeration $\left( \pm 5^{\circ} \mathrm{C}\right)$ and the other at room temperature $\left(22 \pm 2{ }^{\circ} \mathrm{C}\right)$. After 7 and $14 \mathrm{~d}$, the same experiment described above using the L. philippiana powder stored at room temperature and refrigeration was repeated. The variables evaluated were mortality and adult emergence and each treatment had five replicates.

\section{Experimental design and statistical analysis}

To achieve homogeneity of variances, data were transformed to $\sqrt{\mathrm{x}}+0.5$ and subjected to ANOVA $(\alpha=$ 0.05 ) and a Tukey test of comparison of means with a significance of $95 \%(P \leq 0.05)$ using Statistical Analysis System software (SAS Institute, 1998). 


\section{RESULTS AND DISCUSSION}

\section{Insecticidal properties}

Mortality. Higher is the L. philippiana powder concentration higher is the S.zeamais mortality. According to Lagunes (1994), who considers as promising treatments with a mortality over $40 \%$, among evaluated treatments only the concentration of $0.25 \%$ of $L$. philippiana powder not exceed that threshold (Table 1). This concentration exhibited a mortality of $15.69 \%$, significantly lower than other treatments. Concentrations of $0.5,1,2$, and $4 \%$ showed a mortality of $S$. zeamais of $61.9,94.7$, and $100 \%$ respectively, being $0.5 \%$ significantly different (P $\leq 0.05$ ) with the other concentrations. Our results with $L$. philippiana powder are higher than Bittner et al. (2008), who obtained mortality less than $20 \%$ with essential oil.

The insecticidal effect of L. philippiana powder could be associated with alkaloids, like anonaine, asimilobine, and norcoridine, located in bark and leaves (Urzúa and Cassels, 1982), which can acting individually or join causing the insecticidal effect. This inference is due to alkaloids derivatives from plants as lupine (Lupinus spp.) (Wyrostkiewicz et al., 1996), tobacco (Nicotiana tabacum L.) (Yzuru, 1970), or coca (Erythroxylum coca Lam.) (Nathanson et al., 1993) that have shown insecticidal properties.

Adult emergence. All concentrations of L. philippiana foliage powder are considered as promising in the $F_{1}$ reduction because as was proposed by Lagunes (1994), all showed an emergence at least $50 \%$ smaller than control. Concentrations of 1,2, and $4 \%$ had no insect emergence $(0 \%)$. The higher $S$. zeamais emergence was obtained with concentrations of 0.25 and $0.5 \%$ of L. philippiana leaf powder with 37.5 and $7.98 \%$ of emergence respectively (Table 1). At $0.5 \%$ our results agree with Cruzat et al. (2009) and Núñez et al. (2010) but differ with Silva et al. (2005a) because, at the same concentration of $P$. boldus powder, reported an emergence of $59.8 \%$ (Table 2). At concentrations of 1 and $2 \%$ of L. philipiana powder there was no adult emergence being similar to Páez et al. (1991), Silva et al. (2005a), Cruzat et al. (2009), Bustos et al. (2009), and Núñez et al. (2010) (Table 2). However,

Table 1. Mortality and adult insect emergence of Sitophilus zeamais and grain weight loss of stored maize treated with Laureliopsis philippiana powder at $0.25,0.5 ; 1,2$ and $4 \%(w / w)$ concentrations.

\begin{tabular}{lccc}
\hline Concentration & Mortality & Emergence & Weight loss \\
\hline 0.25 & $\%$ & & $\mathrm{~g}$ \\
0.50 & $15.69 \mathrm{c}$ & $37.50 \mathrm{~b}$ & $1.76 \mathrm{~b}$ \\
1.0 & $61.90 \mathrm{~b}$ & $7.98 \mathrm{c}$ & $1.49 \mathrm{cb}$ \\
2.0 & $94.67 \mathrm{a}$ & $0.00 \mathrm{~d}$ & $0.94 \mathrm{~cd}$ \\
4.0 & $100.00 \mathrm{a}$ & $0.00 \mathrm{~d}$ & $0.79 \mathrm{~d}$ \\
Control & $100.00 \mathrm{a}$ & $0.00 \mathrm{~d}$ & $0.77 \mathrm{~d}$ \\
CV, \% & -- & $100.00 \mathrm{a}$ & $3.14 \mathrm{a}$ \\
\hline
\end{tabular}

Within a column, values with the same letter are not significantly different (Tukey, $\mathrm{p} \leq$ $0.05)$.

$\mathrm{CV}$ : Coefficient of variation.
Table 2. Emergence of adult insects $\left(F_{1}\right)$ in different research under laboratory conditions using powder of Peumus boldus to Sitophilus zeamais control.

\begin{tabular}{lcc}
\hline Reference & Concentration & $\begin{array}{c}\text { Insect adult } \\
\text { emergence }\left(\mathrm{F}_{1}\right)^{1}\end{array}$ \\
\cline { 2 - 3 } Páez et al. (1991) & 0.5 & 52.8 \\
Silva et al. (2005a) & 1.0 & 95.2 \\
& 0.1 & 77.9 \\
Bustos et al. (2009) & 0.5 & 57.8 \\
Cruzat et al. (2009) & 1.0 & 0.1 \\
& 2.0 & 0.0 \\
Núñez et al. (2010) & 1.0 & 0.0 \\
& 0.5 & 13.4 \\
& 1.0 & 0.0 \\
& 2.0 & 0.0 \\
& 0.5 & 3.9 \\
& 1.0 & 0.2 \\
\end{tabular}

${ }^{1}$ Control's emergence was considered as $100 \%$.

differ from those obtained by Silva et al. (2003b), who with $1 \%$ of $P$. boldus obtained an emergence of $28.8 \%$.

The lower $F_{1}$ has a direct proportional relationship with mortality because high initial mortality prevents insects copulate affecting egg laid. Also according to Lagunes (1994), the foliage's semiochemicals released to environment causes an alteration in the pheromone receptors interrupting the chemical communication between male and female but in the case of L. philipiana this assumption must be corroborated experimentally. Finally, Silva et al. (2003a) proposed that if the grain is covered by powder, female does not receive the necessary stimulus to oviposition.

\section{Grain weight loss}

In this variable, all treatments were significantly lower than control, which showed a weight loss of $3.14 \mathrm{~g}$ (Table 1). Treatments of 0.25 and $0.5 \%$ did not differ statistically among them, losing 1.76 and $1.49 \mathrm{~g}$ respectively, although were significantly greater than 2 and $4 \%$ which lost less than $1 \mathrm{~g}$. These results indicate that if the concentration of L. philippiana powder increases the mortality increases too and the emergence of $S$. zeamais decreases, which together determine a lower grain weight loss. This trend agrees with Silva et al. (2003b), Bustos et al. (2009), and Cruzat et al. (2009).

\section{Grain germination}

The L. philippiana leaf powder did not affect significantly the grain germination resulting in at least $90 \%$ germination at all concentrations evaluated (Table 3), without significant differences $(\mathrm{P}>0.05)$ between treatments and control. The results of this research indicated that $L$. philippiana powder is not toxic to maize grain. These data are consistent with Bustos et al. (2009), who evaluated powder of $P$. boldus at concentrations of 1 and $2 \%$, obtained 96.7 and $93.3 \%$ germination, respectively. Also Silva et al. (2003b) not obtained significant differences among these same concentrations and the control. 
Table 3. Percentage of germination of maize treated with Laureliopsis philippiana powder at $0.25,0.5 ; 1,2$ and $4 \%(\mathrm{w} / \mathrm{w})$ concentrations.

\begin{tabular}{cc}
\hline Concentration & Germination \\
\hline 0.25 & $90.00 \mathrm{a}$ \\
0.50 & $91.11 \mathrm{a}$ \\
1.0 & $94.44 \mathrm{a}$ \\
2.0 & $94.44 \mathrm{a}$ \\
4.0 & $94.44 \mathrm{a}$ \\
Control & $100.00 \mathrm{a}$ \\
CV, \% & 8.12 \\
\hline
\end{tabular}

Within a column, values with the same letter are not significantly different (Tukey, $\mathrm{p} \leq 0.05$ ). $\mathrm{CV}$ : Coefficient of variation.

\section{Repellence}

All concentrations of L. philippiana powder exhibited a repellency index less than 1 so all can be classified as repellent to $S$. zeamais (Table 4). In consequence if the corn grains are mixed with powder of L. philippiana this prevents the insect colonization. In addition, similar results have been reported by Núnez et al. (2010), who obtained repellency indexes of $0.43,0.18$, and 0.11 for concentrations of $0.5,1$, and $2 \%$ of $P$. boldus powder respectively. This trend is repeated in the bioassay by Cruzat et al. (2009), who evaluated the same variable with powder of $P$. boldus against $S$. zeamais in different cultivars of wheat (Triticum aestivum L.), recording repellency indexes of $0.48,0.64$, and 0.43 .

\section{Fumigant effect}

The treatments of L. philippiana powder do not have fumigant properties, since in all concentrations evaluated showed $0 \%$ S. zeamais mortality. Our results differ of Nuñez et al. (2010), who reported a mortality of 33.3, 46.6, and $31.6 \%$ at $0.5,1$, and $2 \%$ concentrations of $P$. boldus leaves powder. Considering the results of this bioassay to obtain an effective protection of stored grain, is strictly necessary to mix the powder with grains, because the toxicity of L. philippiana leaf powder on $S$. zeamais is by contact and/or ingestion.

\section{Residual effect}

The three concentrations evaluated do not show significant difference of residual effect of L. philippiana leaf fresh powder on S. zeamais and all exceeded $95 \%$ mortality (Table 5). This is similar to Páez et al. (1991) and Silva et al. (2005a), who evaluated the residual effect

Table 4. Repellence index of Sitophilus zeamais adults in maize treated with Laureliopsis philippiana powder at $0.25,0.5 ; 1,2$, and $4 \%$ (w/w) concentrations.

\begin{tabular}{cc}
\hline Concentration & $\begin{array}{c}\text { Repellence index } \\
(\text { IR })^{1}\end{array}$ \\
\hline 0.25 & \\
0.5 & $0.15 \mathrm{R}$ \\
1.0 & $0.12 \mathrm{R}$ \\
2.0 & $0.08 \mathrm{R}$ \\
4.0 & $0.04 \mathrm{R}$ \\
& $0.00 \mathrm{R}$
\end{tabular}

${ }^{1} I R=1$ Neutral (N), IR $<1$ Repellent (R), IR $>1$ Attracting (A).
Table 5. Percentage of mortality of Sitophilus zeamais adults treated with foliage powder of Laureliopsis philippiana, stored by 7 and $14 \mathrm{~d}$ at environmental conditions and refrigeration.

\begin{tabular}{lcccccr}
\hline & & \multicolumn{2}{c}{$\begin{array}{c}\text { Environmental } \\
\text { conditions }\end{array}$} & & \multicolumn{2}{c}{ Refrigeration } \\
\cline { 3 - 4 } \cline { 6 - 7 } $\begin{array}{l}\text { Concentration } \\
\text { (\%) }\end{array}$ & $24 \mathrm{~h}$ & $7 \mathrm{~d}$ & $14 \mathrm{~d}$ & & $7 \mathrm{~d}$ & $14 \mathrm{~d}$ \\
\hline 1.0 & $98.33 \mathrm{a}$ & $100.00 \mathrm{a}$ & $83.33 \mathrm{~b}$ & & $100.00 \mathrm{a}$ & $76.70 \mathrm{~b}$ \\
2.0 & $100.00 \mathrm{a}$ & $100.00 \mathrm{a}$ & $100.00 \mathrm{a}$ & & $100.00 \mathrm{a}$ & $100.00 \mathrm{a}$ \\
4.0 & $100.00 \mathrm{a}$ & $100.00 \mathrm{a}$ & $100.00 \mathrm{a}$ & & $100.00 \mathrm{a}$ & $100.00 \mathrm{a}$ \\
$\mathrm{CV}, \%$ & 4.96 & 0.00 & 4.03 & & 0.00 & 4.63 \\
\hline
\end{tabular}

Within a column, values with the same letter are not significantly different (Tukey, $\mathrm{p} \leq 0.05$ ). $\mathrm{CV}$ : Coefficient of variation.

of $P$. boldus powder, obtained a mortality of 24,100 and 98\% respectively. Treatments of 2 and $4 \%$ had a $100 \%$ mortality coinciding with Silva et al. (2005a).

The evaluation of powder stored for $7 \mathrm{~d}$, at all concentrations assessed under refrigerated and environmental conditions, showed $100 \%$ mortality showing no statistical differences among treatments or powder storage conditions. After $14 \mathrm{~d}$ of storage the concentrations of 2 and $4 \%$ with powder at room temperature or kept refrigerated reached $100 \%$ mortality, higher than reported by Silva et al. (2005b), who evaluated the residual effect of maize mixed with powder of $P$. boldus leaves and stem and foliage of Chenopodium ambrosioides L. (Chenopodiaceae), stored for $15 \mathrm{~d}$ at room temperature in a concentration of $2 \%$, founding that S. zeamais mortality decreases from 100 to $32.15 \%$.

Regarding adult insect emergence, fresh powder of L. phillipiana at concentrations of 1,2 , and $4 \%$, did not have emergence, differing statistically with control, which showed an average emergence, by replication, of 11 insects (Table 6). These results are similar to Silva et al. (2005a), who using powdered leaves of P. boldus, obtained an emergence of 4.7 and $0 \%$ at concentrations of 1 and $2 \%$ respectively. Powder stored by 7 and $14 \mathrm{~d}$ either under refrigeration or room temperature revealed the same trend. In the case of $7 \mathrm{~d}$ all concentrations evaluated did not show adult insect emergence, in contrast to controls that show $F_{1}$ of twelve and ten insects for powder stored in room temperature and refrigeration respectively. Finally, using powder of $14 \mathrm{~d}$ both under refrigeration and at room temperature conditions the adult insect emergence was $0 \%$, differing all concentrations with control that had an emergence average of nine adult insects per replicate.

Table 6. Emergence $\left(\mathrm{F}_{1}\right)$ of Sitophilus zeamais adult treated with foliage powder of Laureliopsis philippiana, stored by 7 and $14 \mathrm{~d}$ at environmental conditions and refrigeration.

\begin{tabular}{lcccccc}
\hline & & \multicolumn{2}{c}{$\begin{array}{c}\text { Environmental } \\
\text { conditions }\end{array}$} & & \multicolumn{2}{c}{ Refrigeration } \\
\cline { 3 - 4 } \cline { 6 - 7 } \begin{tabular}{l} 
Treatment \\
\cline { 6 - 7 }$(\%)$
\end{tabular} & $24 \mathrm{~h}$ & $7 \mathrm{~d}$ & $14 \mathrm{~d}$ & & $7 \mathrm{~d}$ & $14 \mathrm{~d}$ \\
\hline 1.0 & $0.00 \mathrm{~b}$ & $0.00 \mathrm{~b}$ & $0.00 \mathrm{~b}$ & & $0.00 \mathrm{~b}$ & $0.00 \mathrm{~b}$ \\
2.0 & $0.00 \mathrm{~b}$ & $0.00 \mathrm{~b}$ & $0.00 \mathrm{~b}$ & & $0.00 \mathrm{~b}$ & $0.00 \mathrm{~b}$ \\
4.0 & $0.00 \mathrm{~b}$ & $0.00 \mathrm{~b}$ & $0.00 \mathrm{~b}$ & & $0.00 \mathrm{~b}$ & $0.00 \mathrm{~b}$ \\
Control & $11.00 \mathrm{a}$ & $12.00 \mathrm{a}$ & $10.00 \mathrm{a}$ & & $10.00 \mathrm{a}$ & $9.00 \mathrm{a}$ \\
CV, \% & 0.00 & 0.00 & 0.00 & & 0.00 & 0.00 \\
\hline
\end{tabular}

Within a column, values with the same letter are not significantly different (Tukey, $\mathrm{p} \leq 0.05$ ). $\mathrm{CV}$ : Coefficient of variation. 
The results obtained in this study indicate that $L$. philippiana powder have insecticidal properties similar than other plants with insecticidal properties against $S$. zeamais as P. boldus or C. ambrosioides.

\section{CONCLUSIONS}

The foliage powder of L. philippiana is effective as contact insecticide and repellent to $S$. zeamais under laboratory conditions without affecting maize grain germination.

\section{Bioactividad del polvo de tepa (Laureliopsis philippiana (Looser) Shodde) para el control de Sitophilus zeamais Motschulsky en laboratorio. El gorgojo del maíz (Sitophilus zeamais Motschulsky) es una de las plagas que provoca pérdidas a los granos almacenados más importantes a nivel mundial. El control de esta especie se realiza fundamentalmente con aplicaciones continuas de insecticidas organofosforados y piretroides y fumigantes como fosfuro de aluminio, pero problemas con éstos han hecho necesaria la búsqueda y desarrollo de nuevos métodos de control. Se evaluó el efecto insecticida del polvo de hojas de tepa, Laureliopsis philippiana (Looser) Shodde, sobre el gorgojo del maíz en condiciones de laboratorio. Los parámetros evaluados fueron mortalidad y emergencia de insectos adultos, pérdida de peso y germinación de los granos, además de residualidad, repelencia y efecto fumigante. La mayor mortalidad de insectos se registró con los tratamientos 1 , 2 y $4 \%$, con valores entre 94,7 y $100 \%$. Con estas mismas concentraciones se obtuvo una emergencia de insectos adultos de $0 \%$. La pérdida de peso de los granos no superó los 5,7 g en todos los tratamientos y la germinación de semillas no fue afectada. El polvo de L. philippiana mostró efecto repelente en todas las concentraciones y ninguna de ellas presentó acción fumigante. El efecto insecticida del polvo se mantuvo durante $14 \mathrm{~d}$. Finalmente, se concluye que el polvo de L. philippiana tiene gran potencial para el control de $S$.zeamais.}

Palabras clave: granos almacenados, insecticidas vegetales, gorgojo del maíz.

\section{LITERATURE CITED}

Abbott, W.A. 1925. A method for computing the effectiveness of an insecticide. Journal of Economic Entomology 18:265-267.

Bittner, M., M. Aguilera, V. Hernández, C. Arbert, J. Becerra, and M.E. Casanueva. 2009. Fungistatic activity of essential oils extracted from Peumus boldus Mol., Laureliopsis philippiana (Looser) Schodde and Laurelia sempervirens (Ruiz \& Pav) Tul (Chilean monimiaceae). Chilean Journal of Agricultural Research 69:30-37.

Bittner, M., M.E. Casanueva, C. Arbert, M. Aguilera, V. Hernández, and J. Becerra. 2008. Effects of essential oils from five plants species against the granary weevil Sitophilus zeamais and Acanthoscelides obtectus (Coleoptera). Journal of Chilean Chemical Society 53:1455-1459.
Bustos, G., F. Osses, G. Silva, M. Tapia, R. Hepp, and J.C. Rodríguez. 2009. Insecticidal properties of Peumus boldus Molina powder alone and mixed with lime against Sitophilus zeamais Motschulsky (Coleoptera: Curculionidae). Chilean Journal of Agricultural Research 69:350-355.

Celis, J., and K. Kunadu-Yiadom. 1992. Pest control by nonchemical methods and reduced levels of chemicals in grain storage: a review. Agro Sur 20:56-65.

Coats, J.R. 1994. Risks from natural versus synthetic insecticides. Annual Review of Entomology 39:489-515.

Cruzat, M., G. Silva, H. Serri, y R. Hepp. 2009. Protección de ocho cultivares de trigo con polvo de Peumus boldus Molina contra Sitophilus zeamais Motschulsky. IDESIA (Chile) 37:39-46.

González, R. 1989. Insectos y ácaros de importancia agrícola y cuarentenaria en Chile. Universidad de Chile/BASF, Santiago, Chile.

Halstead, D.G.H. 1963. External sex differences in stored-products coleoptera. Bulletin of Entomology Research 54:119-134.

Isman, M. 2006. Botanical insecticides, deterrents, and repellent in modern agriculture and increasingly regulated World. Annual Review of Entomology 51:45-66.

Lagunes, A. 1994. Extractos y polvos vegetales, y minerales para el combate de plagas del maíz y del frijol en la agricultura de subsistencia. Colegio de Postgraduados-USAID-CONACYTBORUCONSA, Montecillo, México

Larraín, P. 1994. Manejo integrado de plagas en granos almacenados. Investigación y Progreso Agropecuario La Platina 81:10-16.

Mazzonetto, F., and J. Vendramim. 2003. Efeito de pós de origem vegetal sobre Acanthoscelides obtectus (Say) (Coleoptera: Bruchidae) em Feijao armazenado. Neotropical Entomology 32:145-149

McLemore, J., W. Bridges, A. Lee, and F. Tainter. 1999. Selected mechanical and physical properties of Chilean tepa wood affected by butterfly stain. Forest Products Journal 49:59-64.

Nathanson, J.A., E.J. Hunnicutt, L. Kantham, and C. Scavone. 1993. Cocaine as a naturally occurring insecticide. Proceeding of National Academy of Science 90:9645-9648.

Novo, R., A. Viglianco, y M. Nassetta. 1997. Actividad repelente de diferentes extractos vegetales sobre Tribolium castaneum (Herbest). Agriscientia 14:31-36.

Núñez, P., G. Silva, M. Tapia, R. Hepp, J.C. Rodríguez, y A. Lagunes 2010. Toxicidad de polvos de follaje de paico (Chenopodium ambrosoides L.) y boldo (Peumus boldus Mol.) solos y en mezcla con carbonato de calcio sobre gorgojo del maíz (Sitophilus zeamais Motschulsky). Agro-Ciencia 26:71-80.

Páez, A., A. Lagunes, J.L. Carrillo, y J.C. Rodríguez. 1991. Polvos vegetales y materiales inertes para el combate del gorgojo del maíz Sitophilus zeamais (Coleóptera: Curculionidae) en maíz almacenado. Agrociencia (México) 3:35-46.

Pérez, F., G. Silva, M. Tapia, y R. Hepp. 2007. Variación anual de las propiedades insecticidas de Peumus boldus Mol. sobre Sitophilus zeamais Motschulsky. Pesquisa Agropecuaria Brasileira 42:633639.

Procopio, S., J. Vendramin, J. Ribeiro, and J. Santos. 2003. Bioatividade de diversos pós de origen vegetal em relaçao a Sitophilus zeamais Mots. (Coleoptera: Curculionidae). Ciencia e Agrotecnologia 27:1231-1236.

Rafael, B., G. Mareggiani, A. Fraschina, y G. Bilotti. 1999. Determinación de la actividad insecticida de Solanum sisymbriifolium, Cestrum parqui y Chenopodium album sobre adultos de Tribolium castaneum (Coleóptera: Tenebrionidae) Revista Facultad de Agronomía 20:373-377.

Rodríguez, C., y A. Lagunes. 1992. Plantas con propiedades insecticidas. Agroproductividad 1:17-25.

Salvadores Y., G. Silva, M. Tapia, y R. Hepp. 2007. Polvos de especias aromáticas para el control de gorgojo del maíz, Sitophilus zeamais Motschulsky en trigo almacenado. Agricultura Técnica 67:147-154.

SAS Institute. 1998. UNIX Environment and derivatives. Versión 6. SAS Institute Inc., Cary, North Carolina, USA. 
Silva, G., P. González, R. Hepp, y P. Casals. 2004. Control de Sitophilus zeamais con polvos inertes. Agrociencia (México) 38:529-536

Silva, G., R. Kiger, R. Hepp, y M. Tapia. 2005b. Control de Sitophilus zeamais con polvos vegetales de tres especies del género Chenopodium. Pesquisa Agropecuaria Brasileira 40:953960.

Silva, G., A. Lagunes, y J. Rodríguez. 2003a. Control de Sitophilus zeamais (Coleóptera: Curculionidae) con polvos vegetales solos y en mezcla con carbonato de calcio en maíz almacenado. Ciencia e Investigación Agropecuaria 30:153-160.

Silva, G., O. Orrego, R. Hepp, y M. Tapia. 2005a. Búsqueda de plantas con propiedades insecticidas para el control de Sitophilus zeamais en maíz almacenado. Pesquisa Agropecuaria Brasileira 40:11-17.

Silva, G., D. Pizarro, P. Casals, y M. Berti. 2003b. Evaluación de plantas medicinales en polvo para el control de Sitophilus zeamais Motschulsky en maíz almacenado. Revista Brasileira Agrociência 9:383-388.
Tavares, M., e J. Vendramin. 2005. Atividade inseticida da erva-desanta-maria, Chenopodium ambrosioides $\mathrm{L}$. (Chenopodiaceae) em relação a Sitophilus zeamais Mots., 1855 (Col.: Curculionidae). Arquivos do Instituto Biologico 72:51-55.

Urzúa, A., and B. Cassels. 1982. Additional alkaloids from Laurelia philippiana and L. novae-zelandiae. Phytochemistry 21:773-776.

Vogel, H., I. Razmilic, y U. Doll. 1997. Contenido de aceite esencial y alcaloides en diferentes poblaciones de boldo (Peumus boldus Mol.). Ciencia e Investigación Agraria 24:1-6.

Wyrostkiewicz, K., M. Wawrzyniak, T. Aniszewski, and K. Gulewicz. 1996. An evidence for insecticide activity of some preparations from alkaloids-rich lupin seeds on Colorado potato beetle (Leptinotarsa decemlineata Say), larvae of the large white butterfly (Pieris brassicae L.), black bean aphid (Aphis fabae Scop.) and on their parasitoids (Hymenoptera: Parasitica) populations. Biological Sciences 44:29-39.

Yzuru, I. 1970. Mode of action of pyrethroids, nicotinoids and rotenoids. Annual Review of Entomology 15:257-272. 